\title{
HYPERACCUMULATION AND MOBILITY OF HEAVY METALS IN VEGETABLE CROPS IN INDIA
}

\author{
Nirmal Kumar J.I. ${ }^{1 *}$, Hiren Soni ${ }^{2}$, Rita N. Kumar ${ }^{3}$ and Ira Bhatt ${ }^{4}$
}

\begin{abstract}
The heavy metals or trace elements play an important role in the metabolic pathways during the growth and development of plants, when available in appreciable concentration. The heavy metal concentration of Cadmium (Cd), Cobalt (Co), Copper ( $\mathrm{Cu}$ ), Iron (Fe), Nickel (Ni), Lead (Pb) and Zinc (Zn) was analyzed using Inductive Coupled Plasma Analyzer (ICPA) (Perkin-Elmer ICP Optima 3300 $\mathrm{RL})$ in 18 vegetable crop plants and their parts along with their soil, collected from various agricultural fields around Anand province, Gujarat, India. The vegetables crop plants were Anthem (Anthum graveolens), Beat (Brassica oleracea), Bitter Gourd (Momordica charantia), Brinjal (Solanum melongena), Cauliflower (Brassica oleracea var. botrytis), Chilli (Capsicum annum), Coriander (Coriandrum sativum), Fenugreek (Trigonella foenum-graceum), Garlic (Alium sativum), Coccinia indica, Lufa (Luffa acutangula), Lady's Finger (Abelmoschus esculentus), Mint (Mentha piperata), Radish (Raphanus sativum), Spinach (Spinacia oleracea), Tomato (Lycopersicum esculentum), Vetches (Cyamopsis soralioides) and White Gourd (Lagernaria vulgaris). The Accumulation Factor (AF) and Mobility Index (MI) were calculated for assessment of mobility of heavy metals from soil to various plant parts: roots, stems and leaves through different levels: Level 1 (Soil-Roots), Level 2 (Roots-Stems) and Level 3 (Stems-Leaves) in studied vegetable crop plants. The results showed concentration dependent variables of heavy metal levels among vegetable crop plants. The lower and higher concentration gradient alongwith their mobility gradient was also determined. A perusal of data reflects that accumulation gradient of each crop plant component vary according to their nature, properties and podsol climate of a particular crop plant. The data on accumulation and mobility of heavy metals such as $\mathrm{Cd}, \mathrm{Co}, \mathrm{Cu}, \mathrm{Fe}, \mathrm{Ni}, \mathrm{Pb}$ and $\mathrm{Zn}$ from soil to leaves through roots and stems, suggested that all the metals were highly mobile.
\end{abstract}

Key words: Vegetable crop plants, heavy metals, accumulation factor, mobility index

\section{INTRODUCTION}

The accumulation of metal ions by root systems is a key function in terrestrial plants, which exhibit extensive ramifications through soil. Distribution of heavy metals in plant body depends upon availability and concentration of heavy metals as well as particular plant species and its population (Punz and Seighardt, 1973). For instance, roots usually show higher heavy metal concentration than shoots, because they are the origin, which comes into contact with the toxic metals present in the soil (Breckle, 1991).

In recent past, Bunzl et al. (2001) investigated soil to plant transfer of heavy metals like, $\mathrm{Cu}, \mathrm{Pb}$ and $\mathrm{Zn}$ by vegetables. Studies on heavy metal uptake reveled that vegetables grown at environmentally contaminated sites in Addis Ababa, Tanzania, could take up and accumulate metals at levels that are toxic to human health. Metal uptake differences by leafy vegetables are attributed to plant differences in tolerance to heavy metals (Itanna, 2002). Cadmium, copper and nickel levels in vegetables from industrial and residential areas of Lagos City, Nigeria was studied by Yusuf et al. (2002), which revealed that levels of Cd, $\mathrm{Cu}$ and $\mathrm{Ni}$ in different edible vegetables alongwith its soils on which they were grown were

\footnotetext{
1 Head, PG Department of Environmental Science and Technology, Institute of Science and Technology for Advanced Studies and Research, Vallabh Vidyanagar - 388 120, Gujarat, India, istares2005@yahoo.com

2 Lecturer, Ashok and Rita Patel Institute of Integrated Study and Research in Biotechnology and Allied Sciences, New Vallabh Vidyanagar - 388 121, Gujarat, India

3 Head, Department of Biosciences and Environmental Sciences

4 N.V. Patel College of Pure and Applied Sciences, Vallabh Vidyanagar - 388 120, Gujarat, India
} 
higher in industrial areas than those of the residential areas due to pollution. Trace element and heavy metal concentrations in fruits and vegetables of the Gediz River region were intensively studied by Delibacak et al. (2002). Also edible portions of five varieties of green vegetables viz. Amaranth, Chinese Cabbage, Cowpea leaves, Leafy Cabbage and Pumpkin leaves collected from several areas in Dar Es Salaam, Africa were analyzed for $\mathrm{Pb}, \mathrm{Cd}, \mathrm{Cr}, \mathrm{Zn}, \mathrm{Ni}$ and $\mathrm{Cu}$. There was a direct positive correlation between $\mathrm{Zn}$ and $\mathrm{Pb}$ levels in soils with levels in vegetables. The relation was absent for other heavy metals (Othman et al. 2002).

In India, similar kind of study was undertaken. Somasundaram et al. (2003) conducted research on heavy metal content of plant samples of sewage-irrigated area of Coimbatore district, Karnataka. Leafy vegetables were found with very high levels of heavy metal contamination including $\mathrm{Cd}, \mathrm{Zn}, \mathrm{Cu}, \mathrm{Mn}$ and $\mathrm{Pb}$. A similar research conducted at Delhi on 'Vegetables eating up vegetarians' found the presence of deadly heavy metals in vegetable samples collected across the capital (The Hindu, 2003).

Rana and Nirmal Kumar (1988) observed heavy metal concentration through Energy Dispersive Analysis of X-Rays (EDAX) in certain sediments in Central Gujarat and noticed that Fe content was found highest in sediment of Undeva region, followed by presence of Si and Al., and Nirmal Kumar et al. (1989) have also investigated elemental composition of certain aquatic plants by EDAX, and found high level of heavy metals such as $\mathrm{Al}, \mathrm{Si}, \mathrm{Mn}$ and Fe accumulated in Vallisnaria spiralis, Hydrilla verticillata and Azolla pinnata. Nirmal Kumar and Rita Kumar (1997) investigated elemental composition of certain economically important plants by EDAX, and encountered the greater accumulation of heavy metals like $\mathrm{Fe}, \mathrm{Cu}$ and $\mathrm{Zn}$ in Mangifera indica, Annona squamosa and Manilcara hexandra, respectively. Nirmal Kumar et al. $(2007,2008)$ analysed concentrations of different heavy metals ( $\mathrm{Cd}, \mathrm{Co}, \mathrm{Cu}, \mathrm{Ni}, \mathrm{Pb}, \mathrm{Zn})$ in market vegetables of Anand vegetable market, Anand town, Gujarat, India, and found that accumulation of heavy metals were higher in Alium cepa $(\mathrm{Cd}, \mathrm{Pb})$, Brassica oleracea var. botrytis (Co, Cu, Fe), Cyamopsis soralioides (Ni), Cucumis sativus (Zn). Leita et al. (1991), Prince et al. (2001) and Nivethitha et al. (2002) have emphasized utilization of heavy metal accumulating plants in reclamation of contaminated soil with heavy metals and assessment of heavy metal mobility in terrestrial ecosystem particularly trophic level of higher plants. However, scanty literature is available on the accumulation and mobility of heavy metals from soil to different vegetable crop plant components. Therefore, the present study was undertaken to visualize the trend of heavy metals in vegetable crop plants and their mobility in various vegetable crop plant components through soil gradient in Anand province, Gujarat, India.

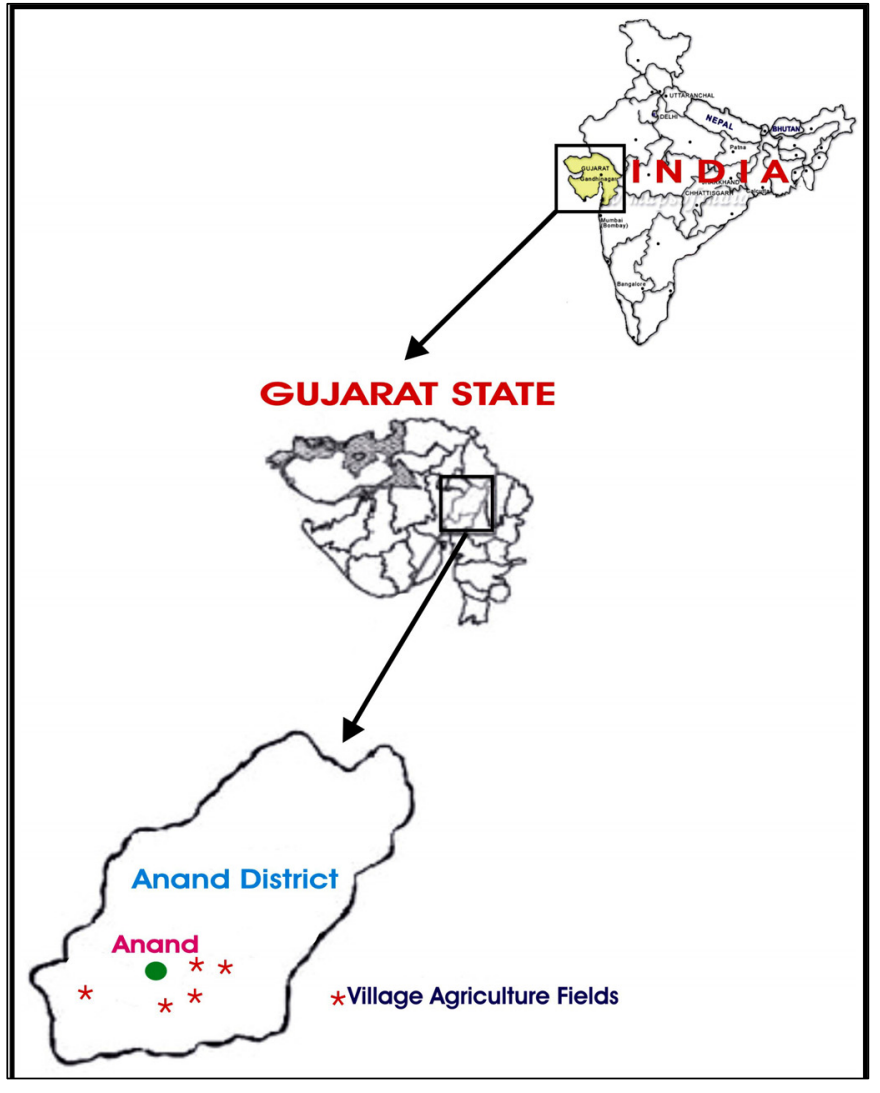

Figure 1: Map showing collection sites 


\section{MATERIALS AND METHODS}

In the present study, 18 fresh vegetable crop plants were collected alongwith their soil from various agricultural fields around Anand province, Gujarat, India (Fig. 1) and brought to the laboratory. The common vegetable crop plants were Abelmoschus esculentus, Alium sativum, Anthum graveolens, Brassica oleracea, Brassica oleracea var. botrytis, Capsicum annum, Coccinia indica, Coriandrum sativum, Cyamopsis soralioides, Lagernaria vulgaris, Luffa acutangula, Lycopersicum esculentum, Mentha piperata, Momordica charantia, Raphanus sativum, Solanum melongena, Spinacia oleracea and Trigonella foenumgraceum. Rhizosphere soil samples for extractable element analysis were also collected from 0 to $20 \mathrm{~cm}$ depth from selected agricultural fields and extracted with DTPA (Diethylene Triamine Penta-acetic Acid), filtered through Whatman filter paper No. 42, and analyzed for element concentration (Lindsary and Norvell, 1978).

All vegetable crop plants were rinsed in double distilled water gently; moisture and water droplets were removed with the help of blotting papers; separated into roots, stems and leaves, and dried before grinding to fine powder. Approximately $0.5 \mathrm{gm}$ of dry powder was weighed by electronic digital monopan balance (Shimadzu Co. BL $22 \mathrm{OH} \mathrm{E}-455000083$, Japan), and digested with $\mathrm{HNO}_{3}, \mathrm{H}_{2} \mathrm{SO}_{4}$ and $\mathrm{H}_{2} \mathrm{O}_{2}$ at the ratio of 2:6:6 as prescribed by Saison et al. (2004). Towards the end of digestion, the flasks were brought to near dryness. The solutions were made to $20 \mathrm{ml}$ each in a measuring cylinder with double distilled water. The blanks were run with set; the samples were then ready for analysis in Industrial Coupled Plasma Analyzer (ICPA) (Perkin-Elmer ICP Optima $3300 \mathrm{Rl}$ ). The concentration of heavy metals such as $\mathrm{Cd}, \mathrm{Co}, \mathrm{Cu}, \mathrm{Fe}, \mathrm{Ni}, \mathrm{Pb}$ and $\mathrm{Zn}$ were analyzed and calculated in $\mu \mathrm{g} \mathrm{g}^{-1}$ in duplicate samples.

As total heavy metal concentration of soils is poor indicator of metal availability for plant uptake, accumulation factor was calculated based on metal availability and its uptake by a particular plant (Brooks et al., 1977). The whole experiment was divided into three categories: Level 1 (Soil-Roots), Level 2 (Roots-Stems) and Level 3 (Stems-Leaves).

Accumulation Factor for plants was calculated as:

Accumulation Factor (AF) =

Mean Plant Concentration ( $\mu \mathrm{g} \mathrm{g}^{-1}$ ) (Roots+Stems+Leaves)

Mean Soil available $\left(\mu \mathrm{g} \mathrm{g}^{-1}\right)$ Concentration

Mobility Index (MI) was calculated for each level by using the formula:

Concentration of Metal $\left(\mu \mathrm{g} \mathrm{g}^{-1}\right)$ in the receiving level

Mobility Index $(\mathrm{MI})=\frac{\text { Concentration of Metal }\left(\mu \mathrm{g} \mathrm{g}^{-1}\right) \text { in the source level }}{\text { Con }}$

\section{RESULTS AND DISCUSSION}

Accumulation and mobility of heavy metals ( $\mathrm{Cd}, \mathrm{Co}, \mathrm{Cu}, \mathrm{Fe}, \mathrm{Ni}, \mathrm{Pb}$ and $\mathrm{Zn}$ ) in vegetable crop plants as a function of concentration are presented in Table 1.

\section{ACCUMULATION OF HEAVY METALS}

During the present study, heavy metals such as $\mathrm{Cd}, \mathrm{Co}, \mathrm{Pb}, \mathrm{Ni}, \mathrm{Cu}, \mathrm{Zn}$ and $\mathrm{Fe}$ were accumulated in particular crop plant components in a very high concentration. It was observed that high content of $C d$ was accumulated in roots of $C$. sativum (0.048), Co in $B$. oleracea var. botrytis roots $(0.318), \mathrm{Pb}$ in roots of $C$. sativum $(0.401), \mathrm{Ni}$ in $C$. sativum 
roots (1.63), $\mathrm{Cu}$ in $A$. sativum roots (2.10), $\mathrm{Zn}$ in roots of $C$. sativum (7.55) and highest concentration of $\mathrm{Fe}$ was found accumulated in roots of $C$. sativum (83.70). Heavy metals also accumulated in stems at different concentrations. Present study revealed that $\mathrm{Cd}$ content was found greater in stems of $C$. annum $(0.021)$, Co in stems of $C$. sativum (0.076), $\mathrm{Pb}$ in $A$. graveolens stems (0.500), $\mathrm{Ni}(0.875)$ in $\mathrm{B}$. oleracea var. botrytis, $\mathrm{Cu}$ (1.26) in stems of $M$. piperata, $\mathrm{Zn} \mathrm{(3.95)} \mathrm{in} \mathrm{stems} \mathrm{of} A$. graveolens and maximum content of Fe was recorded in stems of $C$. sativum being 25.78. High content of $C d$ was accumulated being 0.015 in leaves of $A$. esculentus, $\mathrm{Pb}(0.325)$ in leaves of $R$. sativum, Co (0.387) in C. sativum leaves, $\mathrm{Ni}(1.50)$ in $M$. charantia leaves, $\mathrm{Cu}(1.78)$ in leaves of $C$. sativum, $\mathrm{Zn} \mathrm{(9.43)}$ in leaves of $T$. foenum-graceum and high content of $\mathrm{Fe}$ was accumulated being 89.14 in C. sativum leaves. Thus higher accumulation factor of heavy metals in various plant components particularly in roots, stems and leaves could be found as $\mathrm{Cd}>\mathrm{Co}>\mathrm{Pb}>\mathrm{Ni}>\mathrm{Cu}>\mathrm{Zn}>\mathrm{Fe}$ (Table 1$)$.

On the other hand, it was observed that heavy metals such as $\mathrm{Cd}, \mathrm{Co}, \mathrm{Pb}, \mathrm{Ni}, \mathrm{Cu}, \mathrm{Zn}$ and Fe were present in a low concentration in particular crop plant component. The lowest concentration of $\mathrm{Cd}$ was found in roots of B. oleracea var. botrytis $(0.003)$, Co content in $C$. indica roots $(0.005), \mathrm{Pb}$ in roots of $B$. oleracea var. botrytis $(0.031), \mathrm{Ni}$ in $C$. indica roots

(0.282), Cu in $R$. sativum roots (0.361), $\mathrm{Zn}$ in roots of $A$. esculentus (1.29) and low level of Fe was found in roots of $L$. acutangula (4.10). Stems also accumulated heavy metals upto certain concentration. Present findings revealed that $\mathrm{Cd}$ content was found lowest in stems of M. charantia, $C$. indica and $M$. piperata, $\mathrm{Co}$ in $A$. esculentus, $\mathrm{Pb}$ in $M$. charantia, $\mathrm{Cu}$ in $\mathrm{C}$. annum, $\mathrm{Ni}$ in $A$. sativum, $\mathrm{Zn}$ in L. acutangula and $\mathrm{Fe}$ in M. charantia (2.01). Cd content was very low in leaves of $L$. acutangula $(0.001)$, Co in $A$. esculentus leaves (0.004), $\mathrm{Pb}$ in leaves of $M$. charantia (0.042), Cu in leaves of $M$. piperata $(0.058)$, $\mathrm{Ni}$ in $A$. graveolens leaves (0.199), $\mathrm{Zn}$ in leaves of $B$. oleracea (1.82) and low concentration of $\mathrm{Fe}$ was found in $A$. sativum leaves (5.62). Thus, poor accumulation factor of heavy metals in different crop plant components particularly in roots, stems and leaves could be shown as $\mathrm{Cd}>\mathrm{Co}>\mathrm{Pb}>\mathrm{Ni}>\mathrm{Cu}>\mathrm{Zn}>\mathrm{Fe}$ (Table 1$)$.

In all vegetable crop plants, heavy metal content in plant components was found higher compared to available metal concentration in soil. Cd content was found lowest $(0.14)$ in M. charantia and highest (4.27) in L. vulgaris. Low values of Co and Cu were observed in $C$. indica being 0.04 and 0.21 , respectively, while high content of both the elements were recorded in $C$. soralioides being 3.59 and 2.66, respectively. Poor concentration of Fe was observed in A. sativum (0.02), and high Fe conent was noticed in C. soralioides (2.40). On the other hand, S. oleracea was found to contain low concentration $(0.19)$ of $\mathrm{Ni}$, while high content (1.25) of the same metal was registered in C. sativum. M. charantia exhibited low concentration of $\mathrm{Pb}$ and $\mathrm{Zn}$ being 0.22 and 0.15 , respectively, while higher content (6.81) of $\mathrm{Pb}$ was found in M. piperata and low content was observed in $T$. foenumgraceum being 1.98. Thus heavy metal content $\left(\mu \mathrm{g} \mathrm{g}^{-1}\right)$ in vegetable crop plants ranged from 0.14 to $3.69(\mathrm{Cd}), 0.04$ to $0.42(\mathrm{Co}), 0.21$ to $1.17(\mathrm{Cu})$ and 0.02 to $0.40(\mathrm{Fe})$, while in case of $\mathrm{Ni}$, the concentration ranged from 0.39 to $1.25, \mathrm{~Pb}(0.22$ to 6.81$)$ and $\mathrm{Zn}(0.15$ to 1.98).

In all vegetable crop plants, $\mathrm{Cd}$ content was higher in plant components compared to available Cd level in soil, which might be due to the high uptake and accumulation rate. Similar findings were noticed by Prince et al. (2001). Among all vegetable crop plants, Fe concentration was higher in all three-plant components, could be due to iron-rich soil (Nivethitha et al., 2002; Nirmal Kumar et al., 2007). Mechanism of metal accumulation was found significant in terms of accumulation factor of a particular plant component. Roots showed high accumulation of heavy metals (6.39), followed by moderate 


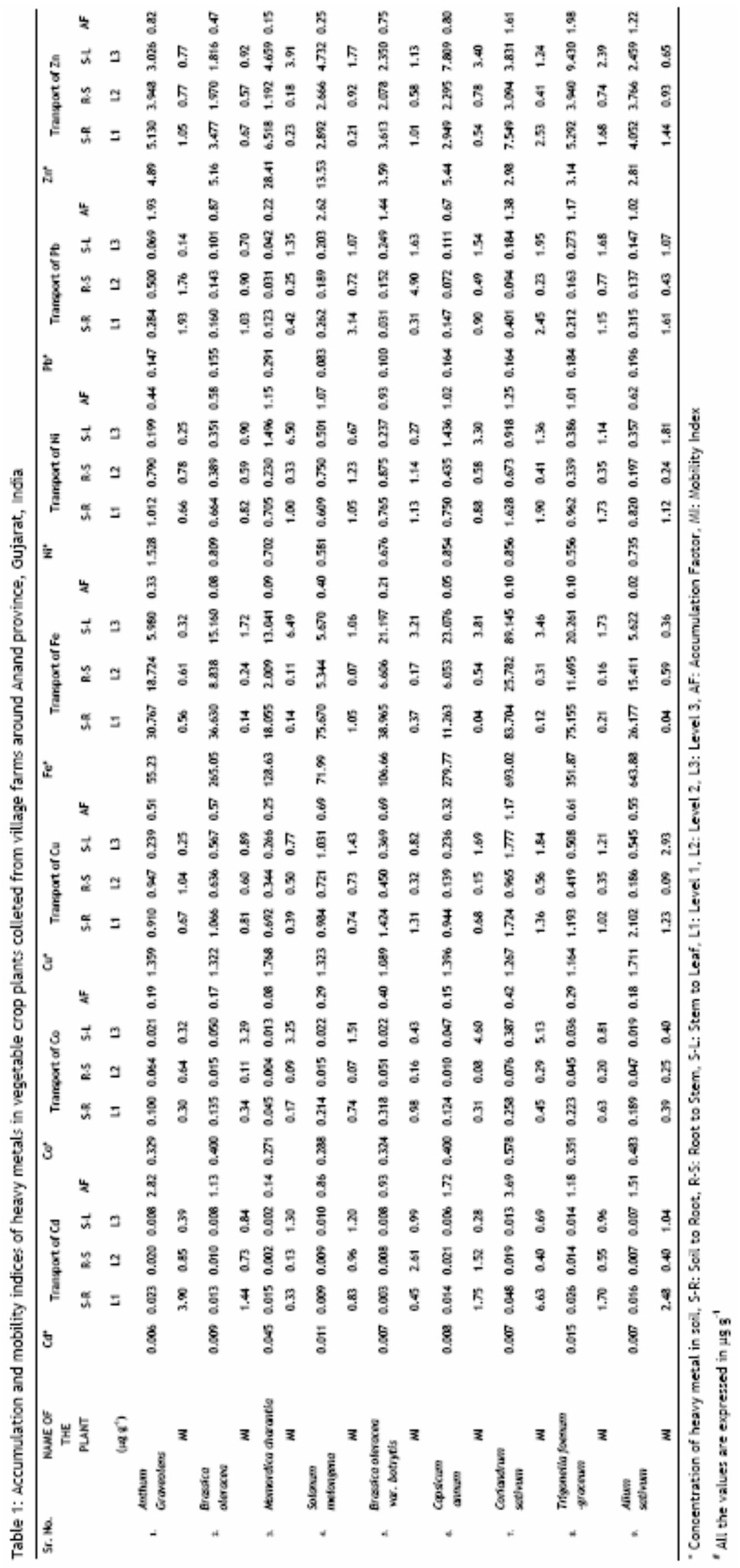




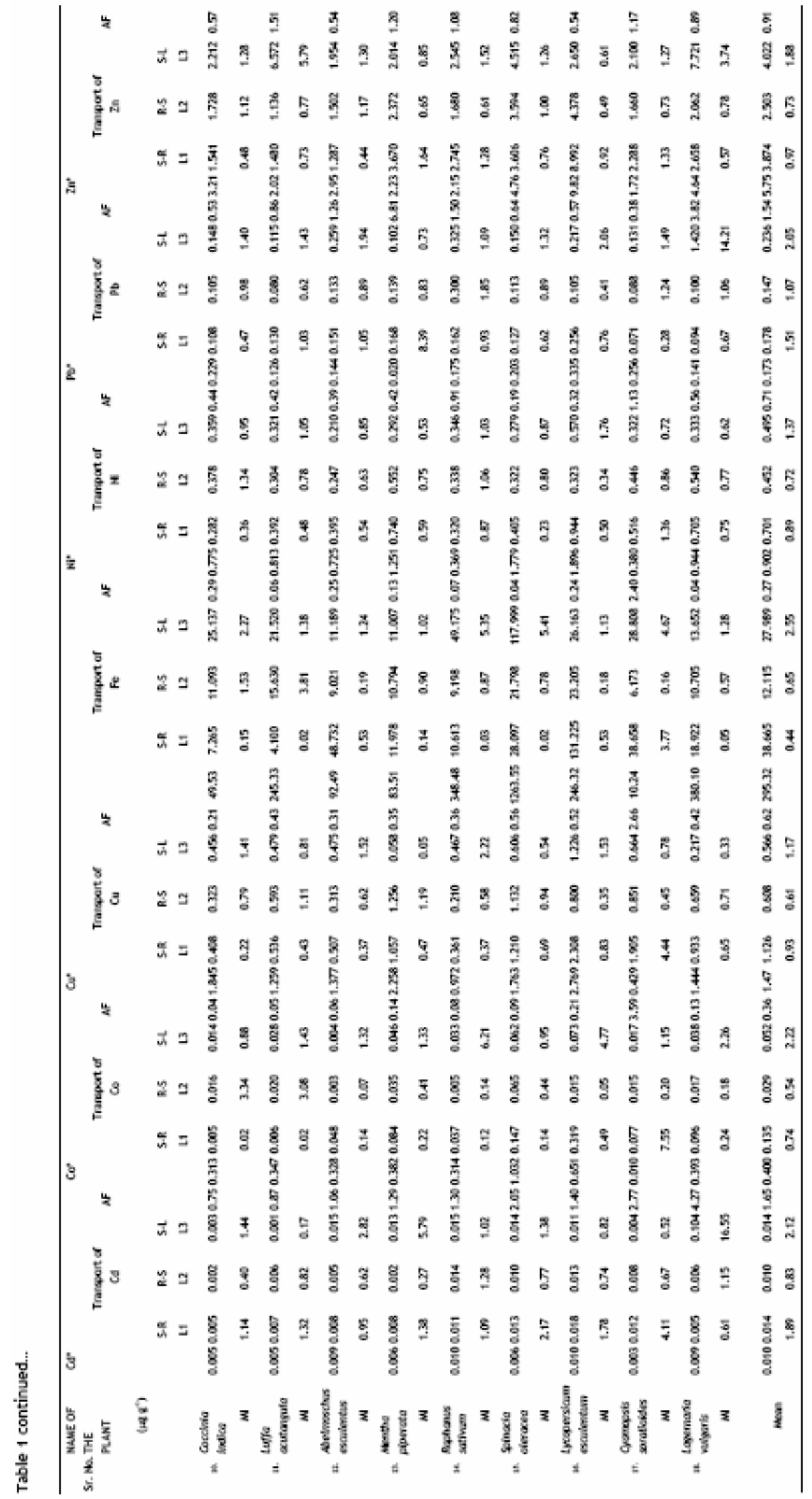


accumulation in leaves (4.77) and the poor content (2.27) in stems. This indicated higher rate of mobility of metals from soil to roots in a particular plant, moderate from stems to leaves, and low from roots to stems. Thus, the present results were well-corroborated with the observations of Hunter et al., (1987a, 1987b, 1987c).

Moreover, the vegetable crop plants such as $M$. charantia and $C$. soralioides were found to be hypo-accumulative and hyper-accumulative, respectively, in nature. Presence of heavy metals such as $\mathrm{Cd}, \mathrm{Pb}$ and $\mathrm{Zn}$ was detected in lowest concentration in M. charantia, while $C$. soralioides was found to accumulate $\mathrm{Co}, \mathrm{Cu}$ and $\mathrm{Fe}$ in high content. Therefore, $\mathrm{C}$. soralioides could be used to decontaminate heavy metals from polluted soils in view of its ability to accumulate various heavy metals several folds higher than their available level within the soil. Therefore, it is recommended that such verities of vegetable crop plants could be effectively used to decontaminate heavy metal polluted soil due to its capability to establish and proliferate in soil podsol (Nivethitha et al., 2002).

\section{MOBILITY OF HEAVY METALS}

Mobility Index (MI) showed biomobility and transport of heavy metals through different levels: Level 1 (Soil-Roots), Level 2 (Roots-Stems) and Level 3 (Stems-Leaves) in vegetable crop plants, which becomes functional to understand the transport mechanism of heavy metals in plant components, such as roots, stems and leaves. Present findings revealed that Level 1 (Soil-Roots) registered high mobility rate of $\mathrm{Ni}$ and $\mathrm{Zn}$ in $\mathrm{C}$. sativum being 1.90 and 2.53, respectively, Fe (3.77) and $\mathrm{Cu}(4.44)$ in $C$. soralioides, $\mathrm{Cd}$ in $C$. sativum (6.63), Co in $C$. soralioides (7.55) and $\mathrm{Pb}$ in $M$. piperata being 8.39. In case of Level 2 (RootsStems), greater mobility rate of $\mathrm{Zn}$ was achieved in $A$. esculentus (1.17); $\mathrm{Cu}$ in M. piperata (1.19), Ni in L. acutangula (1.34), Cd in B. oleracea var. botrytis (2.61), Co in C. indica (3.34), Fe in L. acutangula (3.81) and low mobility rate of $\mathrm{Pb}$ was encountered in $B$. oleracea var. botrytis being 4.90. Thus higher mobility gradient of heavy metals among various levels can be expressed as $\mathrm{Co}>\mathrm{Fe}>\mathrm{Zn}>\mathrm{Cu}>\mathrm{Ni}>\mathrm{Pb}>\mathrm{Cd}$ (Table 1).

Present study also showed that some metals exhibited low mobility rate from one part to other part in particular vegetable crop plant. Low mobility of metals was encountered in Level 1 (Soil-Roots): low mobility of $\mathrm{Co}$ and $\mathrm{Fe}$ in C. indica and L. acutangula $(0.002)$, respectively, $\mathrm{Zn}$ in $\mathrm{S}$. melongena $(0.21), \mathrm{Cu}$ in $\mathrm{C}$. indica $(0.22), \mathrm{Ni}$ in $\mathrm{S}$. oleracea $(0.23), \mathrm{Pb}$ in C. soralioides (0.28) and low transfer of $C d$ was recorded in M charantia (0.33). In case of Level 2 (Roots-Stems), low mobility rate of Co was achieved in L. esculentum (0.05), Fe in S. melongena (0.07), Cu in A. sativum (0.09), $\mathrm{Cd}(0.13)$ and $\mathrm{Zn}(0.18)$ in M. charantia, $\mathrm{Pb}$ in $C$. sativum (0.23) and low mobility of $\mathrm{Ni}$ was registered in $A$. sativum (0.24). Moreover, level 3 (Stems-Leaves) showed low mobility of Cu in M. piperata (0.05), $\mathrm{Pb}$ in $A$. graveolens (0.14), Cd in L. acutangula (0.17), Ni (0.25), Co (0.32) and Fe (0.32) in $A$. graveolens and $\mathrm{Zn}$ in $\mathrm{L}$. esculentum (0.61). Thus, lower mobility rate gradient of heavy metals through different plant components can be expressed as $\mathrm{Co}>\mathrm{Fe}>\mathrm{Zn}>\mathrm{Cu}>\mathrm{Ni}>$ $\mathrm{Pb}>\mathrm{Cd}$ (Table 1).

Rate of mobility was found higher in Cd (1.61), followed by Pb (1.54), Fe (1.21), Zn (1.19), $\mathrm{Co}(1.17)$ and lowest in $\mathrm{Ni}(0.99)$ and $\mathrm{Cu}(0.90)$. Mobility of metals at different levels varied among various plant parts. Mobility factor was ranged from 0.44 to 1.89 in Level 1 (Soil-Roots), 0.54 to 1.07 in Level 2 (Roots-Stems) and 1.17 to 2.55 in Level 3 (StemsLeaves) (Table 1). Thus mobility gradient of heavy metals in plant components could be drawn as $\mathrm{Cd}>\mathrm{Pb}>\mathrm{Fe}>\mathrm{Zn}>\mathrm{Co}>\mathrm{Ni}>\mathrm{Cu}$. Similarly, metal transport mechanism was found significant in terms of mobility of a particular metal content from source to receiving level. High mobility was observed at different levels, which is established by the fact that very low content of heavy metals are transported from roots to stems (Level 2) being only 0.73 . Gradual increase in transport of metal content was observed in Level 1 
(Soil-Roots) with 1.05, while highest content of metals are transported through Level 3 (Stems- Leaves) being 1.90 . This might be due to the fact that $\mathrm{Cd}$ is more readily available than other metals in surface soil horizons, which corroborated the findings of Hunter et al. (1987a, 1987b, 1987c).

Thus concentration of heavy metals was found moderate in roots could be due to increased mobility of heavy metals from soil to roots indicated the tendency of roots to accumulate good amount of metals from soil and transfer a little to above ground biomass. These results are in conformation with the findings of Jarvis et al. (1976) and Leita et al. (1993), who noticed moderate accumulation of heavy metals in root system. It reveals that sometimes roots act as barriers to transfer the toxic metals through soil-plant system (Jones and Clement, 1972). Jarvis and Robson (1982) reported that most of the accumulated $\mathrm{Cu}$ was retained within roots even when plants showed $\mathrm{Cu}$ deficiency symptoms.

\section{CONCLUSION}

1. Higher accumulation factor of heavy metals in various plant components particularly in roots, stems and leaves was found in the order $\mathrm{Cd}>\mathrm{Co}>\mathrm{Pb}>\mathrm{Ni}>\mathrm{Cu}>\mathrm{Zn}>\mathrm{Fe}$.

2. Vegetable crop plants like C. soralioides, B. oleracea var. botrytis, C. annum, A. graveolens and $M$. piperata were found to be hyper-accumulative, whereas, $C$. indica, $A$. esculentus and $L$. acutangula were hypo-accumulative.

3. C. soralioides could be used to decontaminate the heavy metal polluted soils.

4. Greater mobility rate was observed in vegetable crop plants such as $C$. sativum, $C$. soralioides, $M$. piperata and $C$. indica, while poor mobility in $S$. melongena, $S$. oleracea and $L$. esculentum.

5. Mobility of heavy metals such as $\mathrm{Cd}, \mathrm{Co}, \mathrm{Cu}, \mathrm{Fe}, \mathrm{Ni}, \mathrm{Pb}$ and $\mathrm{Zn}$ from soil to leaves suggested that all these metals were highly mobile from soil to plant components.

6. Comparing transfer potential of metals among various plant components, these metals markedly exceeded in Level 3 (Stems-Leaves), followed by a gradual decline in Level 1 (Soil-Roots) and Level 2 (Roots-Stems).

\section{ACKNOWLEDGEMENTS}

Authors are thankful to "Charotar Ratna" and "Shalin Manav Ratna" Dr. C.L. Patel, Chairman, Charutar Vidya Mandal (CVM), Vallabh Vidynagar, Gujarat, India, for being a constant source of inspiration, initiation and motivation to carry out this small piece of work, without whose support this work would not have been possible. Thanks are also due to Dr. Gokul Patel and Mr. Tiwari for their assistance in sample analysis using Industrial Coupled Plasma Analyzer (ICPA) at Sophisticated Instrumentation Center for Applied Research and Testing (SICART), Vallabh Vidynagar, Gujarat, India.

\section{REFERENCES}

Balba, A.M., El-Shebiny, G. and E.A. Elkhatib. (1991). Effect of lead increments on the yield and lead content of tomato plants. Water, Air \& Soil Pollution., 57/58: 93-99.

Breckle, S.W. (1991). Growth under stress: Heavy metals In: Plant Roots-The Hidden Half (Y. Waisel, Eshel, A and Kafkafi, U., eds.), Marcel Dekker, New York. 351-373. 
Bunzl, K., Trautmannsheimer, M., Schramel, P. and W. Reifenhäuser. (2001). Availability of Arsenic, Copper, Lead, Thallium, and Zinc to Various Vegetables Grown in Slag-Contaminated Soils. Journal of Environmental Quality., 30: 934-939.

Delibacak, S., Elmaci, O.L, Secer, M. and A. Bodur. (2002). Trace element and heavy metal concentrations in fruits and vegetables of the Gediz River region. International Journal of Water., 2: 23-29.

Hunter, B.A., Johnson, M.S. and D.J. Thompson. (1987a). Ecotoxicology in copper and cadmium in a contaminated grassland ecosystem. I. Soil vegetation contamination. Journal of Applied Ecology., 24: 573-586.

Hunter, B.A., Johnson, M.S. and D.J. Thompson. (1987b). Ecotoxicology in copper and cadmium in a contaminated grassland ecosystem. II. Invertebrates. Journal of Applied Ecology., 24: 587-599.

Hunter, B.A., Johnson, M.S. and D.J. Thompson. (1987c). Ecotoxicology in copper and cadmium in a contaminated grassland ecosystem. III. Small mammals. Journal of Applied Ecology., 24: 601614.

Itanna, F. (2002). Metals in leafy vegetables grown in Addis Ababa and toxicological implications., Ethiopian Journal of Health Division., 16(3): 295-302.

Jarvis, S.C. and A.D. Robson. (1982). Absorption and distribution of copper in plants with sufficient or deficient supplies. Annals of Botany., 50: 151-160.

Jarvis, S.C., Jones, L.H.P. and Hooper, M.J. (1976). Cadmium uptake from solution by plants and its transport from roots to shoot. Plant and Soil., 44: 179-191.

John, M,K. and C.J. VanLaerhoven. (1972). Lead distribution in plants grown on a contaminated soil., Environmental Letters, 3 (2), 111-116.

John, M.K., C.J. VanLaerhoven and C. Chukwuma. (1972). Factors affecting plant uptake and phytotoxicity of Cadmium added to soils. Environmental Science and Technology., 6(12): 10051009.

Jones, L.H.P. and C.R. Clement. (1972). Lead Uptake by Plants and Its Significance for Animals. In: Lead in the Environment. (P. Hepple, ed.). Applied Science Publishers, Barking. 29-33.

Lee, B.D., Carter, B.J, Basta, N.T and B. Weaver. (1997). Factors influencing heavy metal distribution in six Oklahoma benchmark soils. Soil Science Journal of American Soil Society., 61: 218-223.

Leita, L., Enne, G., De Nobili, M., Baldini, M. and P. Sequi. (1991). Heavy metal bioaccumulation in lamb and sheep bred in smelting and mining areas of S.W. Sardinia (Italy). Bulletin of Environmental Contamination and Toxicology., 46: 887-893.

Li, L and G. Wu. (1999). Numerical Simulation of Transport of Four Heavy Metals in Kaolinite Clay. Journal of Environmental Engineering., 125(4): 314-324.

Lindsary, W.L. and W.A. Norvell. (1978). Development of DTPA soil test for Zn, Fe, Mn and Cu. Journal of American Soil Science., 42: 421-428.

Martin, M. H. and P.J. Coughtrey. (1976). Comparisons between the levels of lead, zinc and cadmium with a contaminated environment. Chemosphere., 5: 15-20.

Nair, M., Balachandran, K.K., V.N.Sankarnarayan and T. Joseph. (1997). Heavy metals in fishes from coastal waters of Cochin, South West Coast of India. Indian Journal of Marine Science., 26: 98100.

Nirmal Kumar, J,I., Soni, H. and R.N. Kumar. (2007). Characterization of heavy metals from market vegetables using Inductive Coupled Plasma Analyzer (ICPA). International Journal of Biosciences Reporter., 5 (1): 71-76.

Nirmal Kumar, J.I. and R.N. Kumar. (1997). Elemental composition of certain economic important plants by EDAX. Proceedings of National Symposium on Plant Morphogenesis., 177-181.

Nirmal Kumar, J.I., Soni, H., Kumar, R.N., and I. Bhatt. (2008). Assessing heavy metal hyperaccumulation and mobility in selected vegetable crops: A case study of organic farm, Gujarat, India. Nature, Environment and Pollution Technology. 7 (2): 203-210. 
Nirmal Kumar, J.I., Sreenivas, S.S and B.C. Rana. (1989). EDAX- analysis of mud of four ponds from Central Gujarat., Indian Botanical Contractor., 6: 75-76.

Nivethitha, P., Thnagavel, P., Prince, S.P.M.W. and Subburam, V. (2002). Identification of heavy metal accumulating plants and their use in reclamation of soil contaminated with heavy metals. International Journal of Ecology, Environment and Conservation., 8(3): 249-251.

Othman, O.C. (2001). Heavy metals in green vegetables and soils from vegetable gardens in Dar Es Salaam, Tanzania., Tanzanian Journal of Science., 27: 37-48.

Peles, J., Brewer, S and G. Barrett. (1998). Heavy metal accumulation by old-field plant species during recovery of sludge-treated ecosystems. The American Midland Naturalist., 140(2): 245251.

Prince, S.P.M.W., Senthilkumar, P. and Subburam, V. (2001). Mulberry-Silkworm food chain - A templet to assess heavy metal mobility in terrestrial ecosystems. Environmental Monitoring and Assessment., 69:231-238

Punz, W.F. and H. Sieghardt. (1993). The response of roots of herbaceous plant species to heavy metals. Environment and Experimental Botany., 33(1): 85-98.

Rana, B.C and J.I. Nirmal Kumar. (1988). Energy Dispersal Analysis of X-rays of certain aquatic macrophytes. Indian Journal of Weed Science., 20: 46-49.

Saison, C., Schwartz, C. and J.L. Morel. (2004). Hyperaccumulation of metals by Thlaspi caerulescens as affected by root development and $\mathrm{Cd}-\mathrm{Zn} / \mathrm{Ca}-\mathrm{Mg}$ interactions. International Journal of Phytoremediation., 6(1): 49-61.

Somasundaram, J. (2003). Imbibing toxic/heavy metals through leafy vegetables. In: The Hindu, Online edition of India's National Newspaper, 6th November 2003.

The Hindu. (2003). Vegetables eating up vegetarians. The Hindu., 27th March, New Delhi.

Todd, G.C. (1996). Vegetables grown in mine wastes. Environmental Toxicology and Chemistry., 19(3): 600-607.

Yusuf, A.A., Arowolo, T.O.A. and O. Bamgbose. (2002). Cadmium, copper and nickel levels in vegetables from industrial and residential areas of Lagos City, Nigeria. Global Journal of Environmental Science., 1(1): 1-6. 